\title{
INVESTIGATION OF GRAIN BOUNDARIES IN ALLOY 263 AFTER SPECIAL HEAT TREATMENT
}

\author{
PREISKAVA MEJ ZRN V ZLITINI 263 PO POSEBNI TOPLOTNI \\ OBDELAVI
}

\author{
Ivan Slatkovský, Mária Dománková, Martin Sahul \\ Slovak University of Technology Bratislava, Faculty of Materials Science and Technology, Institute of Materials Science, \\ Bottová 25, 917 24, Trnava, Slovak Republic \\ ivan.slatkovsky@stuba.sk
}

Prejem rokopisa - received: 2016-06-20; sprejem za objavo - accepted for publication: 2017-01-24

doi: $10.17222 / \mathrm{mit} .2016 .115$

\begin{abstract}
Alloy 263 is well known for its very good creep resistance and also for its weldability. These kinds of properties are appreciated in the power-plant industry where Alloy 263 is used for shafts in a high-pressure circle. One of the possible ways to improve the properties of superalloys, including Alloy 263, is through the effect of the grain-boundary serration (GBS) which, as research indicates, is associated with the improvement of the creep resistance that can lead to an increased efficiency of coal power plants. Grain-boundary serration was observed in different kinds of superalloys although the formation mechanism of serration has not been clearly explained yet. Some researchers reported that the formation of serration is associated with the change in the character of the precipitates at grain boundaries. This paper deals with an investigation of the grain boundaries in Alloy 263 using two different kinds of heat treatment. To form serrated grain boundaries in Material A (MA), slow controlled cooling from the temperature of solution annealing to $800{ }^{\circ} \mathrm{C}$ was carried out. Standard heat treatment of Alloy 263 was performed on material B (MB). Experimental techniques of scanning electron microscopy (SEM) and transmission electron microscopy (TEM), including electron diffraction, were used to analyze the microstructure, determine the character of the grain boundaries and identify the secondary particles at the grain boundaries.
\end{abstract}

Keywords: Alloy 263, grain-boundary serration, precipitates

Zlitina 263 je znana po zelo dobri odpornosti proti lezenju in tudi po dobri varivosti. Te vrste lastnosti so zelo cenjene v termoelektrarnah, kjer se zlitina 263 uporablja za gredi v visokotlačnem delu turbin. Eden od možnih načinov za izboljšanje lastnosti superzlitin, vključno z zlitino 263, je tvorba (nastanek) nazobčanih kristalnih mej (angl. GBS). Preiskava je pokazala, da je ta fenomen povezan $\mathrm{z}$ izboljšanjem odpornosti proti lezenju, kar lahko vodi $\mathrm{k}$ večji učinkovitosti termoelektrarn na premog. Učinek nazobčanosti mej kristalnih zrn so opazili pri različnih vrstah superzlitin, čeprav mehanizem tvorbe še ni popolnoma pojasnjen. Nekateri raziskovalci so ugotovili, da je tvorba nazobčanosti povezana s spremembo lastnosti izločkov na mejah med zrni. Prispevek se ukvarja s preiskavo mej med kristalnimi zrni v zlitini 263 z dvema različnima vrstama toplotne obdelave. Nastanek nazobčanih mej kristalnih zrn materiala A (MA), je bil povzročen s počasnim kontroliranim ohlajanjem iz temperature raztopnega žarjenja, ki je bila $800^{\circ} \mathrm{C}$. Standardna toplotna obdelava se je izvajala za zlitino 263 - material B (MB). $\mathrm{Za}$ analizo mikrostrukture so uporabili vrstični elektronski mikroskop (SEM) in presevno elektronsko mikroskopijo (TEM), vključno z elektronsko difrakcijo. Na ta način so določili lastnosti mej kristalnih zrn in sekundarnih delcev na mejah zrn.

Ključne besede: zlitina 263, nazobčanost mej kristalnih zrn, izločki

\section{INTRODUCTION}

It is a well-known fact that a reduction in the $\mathrm{CO}_{2}$ emissions produced by coal power plants is one of the major goals for the countries all over the world. A possible way to reduce the $\mathrm{CO}_{2}$ emissions is to improve thermal efficiencies through super critical and ultrasuper critical technologies in power plants, where efficiencies above $40 \%$ could be reached. Hence, to achieve this kind of efficiency, the materials like nickelbased superalloys are considered to be used (Figure 1). ${ }^{1-3}$

To prolong the life time of parts when the temperature exceeds $700{ }^{\circ} \mathrm{C}$, scientists are looking for new paths of material processing. In the case of heat treatment, one of the possible ways is a modification of grain boundaries (GBs) when the character of the boundaries changes from straight to zigzag.
The phenomenon of grain-boundary serration (GBS) was observed in the nickel-based superalloys and in austenitic stainless steels. The formation of serrations on grain boundaries (GBs) has not been fully described yet. However, it is a known fact that in the case of nickelbased superalloys, the GBS is closely related to the slow controlled cooling from the temperature of the solution annealing.

Early studies of serration in the nickel-based alloys were focused on the interaction between the grain boundary and $\gamma$ ' phase. ${ }^{4,5}$ Until now, researchers have found that the serration is associated not only with the presence of the $\gamma^{\prime}$ phase, but also with other precipitates like $\mathrm{M}_{23} \mathrm{C}_{6}$ carbide, the $\sigma$ phase or the $\gamma$ " phase on the GBs that were observed in different kinds of superalloys. The formation of these secondary particles could be highly related to the serrated grain boundaries and their formation. ${ }^{6-13}$ Recently, contemporary authors have 
MATERIALI IN TEHNOLOGIJE/MATERIALS AND TECHNOLOGY (1967-2017) - 50 LET/50 YEARS

I. SLATKOVSKÝ et al.: INVESTIGATION OF GRAIN BOUNDARIES IN ALLOY 263 AFTER SPECIAL HEAT TREATMENT

Table 1: Nominal chemical composition of Alloy 263

\begin{tabular}{|c|c|c|c|c|c|c|c|c|c|}
\hline \multicolumn{9}{|c|}{ Chemical-composition limits } \\
\hline Weight $\%$ & $\mathrm{Ni}$ & $\mathrm{Cr}$ & $\mathrm{Co}$ & $\mathrm{Mo}$ & $\mathrm{C}$ & $\mathrm{Al}$ & $\mathrm{Ti}$ & $\mathrm{Al}+\mathrm{Ti}$ & $\mathrm{Mn}$ \\
\hline 263 & $\mathrm{Bal}$ & $19-21$ & $19-21$ & $5.6-6.1$ & $0.04-0.08$ & $0.60 \mathrm{max}$ & $1.90-2.40$ & $2.40-2.80$ & $0.60 \mathrm{max}$ \\
\hline Weight $\%$ & $\mathrm{Si}$ & $\mathrm{Fe}$ & $\mathrm{Cu}$ & $\mathrm{B}$ & $\mathrm{Pb}$ & $\mathrm{S}$ & $\mathrm{Ag}$ & $\mathrm{Bi}$ & \\
\hline 263 & $0.40 \mathrm{max}$ & $0.07 \mathrm{max}$ & $0.020 \mathrm{max}$ & $0.005 \mathrm{max}$ & 0.0020 & $0.007 \mathrm{max}$ & $0.005 \mathrm{max}$ & $0.0001 \mathrm{max}$ & \\
\hline
\end{tabular}

found that in some alloys, in the early stages of the formation, GBS occurred in the absence of the adjacent coarse $\gamma^{\prime}$ particle or $\mathrm{M}_{23} \mathrm{C}_{6}$ carbide. ${ }^{12-14}$ Furthermore, $\mathrm{H}$. U. Hong et al. ${ }^{15}$ observed in their research that the serrations on GBs were formed in the material after a long solution annealing (2000 min) without any slow controlled cooling. Also, no secondary particles were observed.

As reported by the authors of references, ${ }^{10-13}$ GBS leads to a morphological change of the carbides on GBs, from granular to planar. A growth of secondary particles on the serrated grain boundaries was observed mostly at a low angle and on special GBs. The authors of references ${ }^{10,11}$ reported that the formation of planar $\mathrm{M}_{23} \mathrm{C}_{6}$ carbides is orientated in the $\{111\}$ plane. Also, the orientation relationship between the carbides and the matrix was observed.

Therefore, the purpose of this study is to investigate the effect of special heat treatment on GBs and identify the secondary phases formed at the GBs in Alloy 263.

\section{EXPERIMENTAL PART}

In order to investigate GBS, commercially available hot-rolled nickel-based superalloy 263 was used in the study. The chemical composition of the examined alloy is given in Table $\mathbf{1}$.

A two-stage special heat-treatment method was designed to form a GBS in material A, based on the previous studies. ${ }^{6-13}$ The solution heat treatment followed by slow cooling at a carefully controlled rate (until the aging temperature was reached) was found to be necessary to generate serrated GB structures.

Material A was solution annealed at $1150{ }^{\circ} \mathrm{C}$ for $80 \mathrm{~min}$ and cooled slowly to $800{ }^{\circ} \mathrm{C}$ at a cooling rate of $3{ }^{\circ} \mathrm{C} / \mathrm{min}$, followed by water quenching. After that,

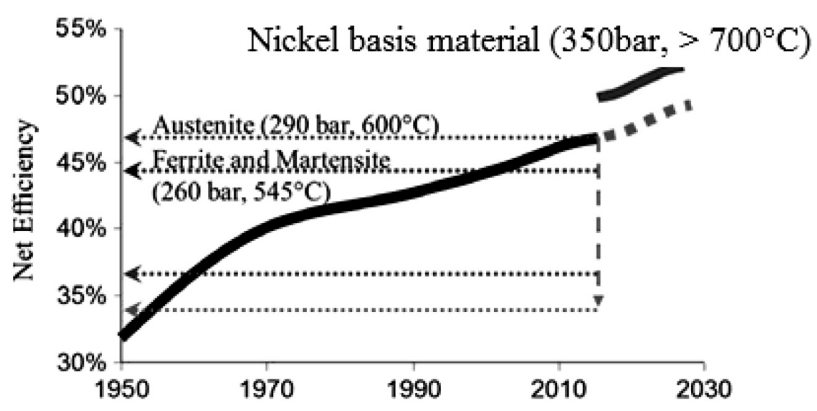

Figure 1: Net efficiency development in the case of hard coal-fired power plants considering different structural alloys ${ }^{3}$ precipitation hardening at $800{ }^{\circ} \mathrm{C}$ for $4 \mathrm{~h}$ was performed and followed by air cooling.

On material B, the standard two-stage heat treatment of Alloy 263 (solution annealing at $1150{ }^{\circ} \mathrm{C}$ for $80 \mathrm{~min}$ followed by water quenching and precipitation hardening at $800{ }^{\circ} \mathrm{C}$ for $4 \mathrm{~h}$, cooled in the air) was applied.

For a SEM analysis, the samples were sliced, mechanically grinded and polished. The etching solution for the SEM observation was a solution containing $5 \mathrm{~g}$ $\mathrm{FeCl}_{3}, 15 \mathrm{~mL} \mathrm{HCl}, 2 \mathrm{~mL} \mathrm{HNO}_{3}$ and $60 \mathrm{~mL}$ ethanol used for $10-15 \mathrm{~s}$ in order to reveal the GB configuration and carbides. A JEOL $7600 \mathrm{~F}$ scanning electron microscope was used for the observation of the GBs.

Thin foils were prepared for a detailed grain-boundary observation using mechanical grinding to a thickness of about $0.1 \mathrm{~mm}$, and then electrolytically etched. Etching was done on TENUPOL 5 in a solution of perchloric acid and methanol (1:9). The temperature during etching was $-30{ }^{\circ} \mathrm{C}$ and the voltage was $25 \mathrm{~V}$. For the detailed observation, a transmission electron microscope, JEOL $200 \mathrm{CX}$ with an accelerating voltage of 200 $\mathrm{kV}$, was used. To identify secondary particles at the GBs, an electron-diffraction analysis was applied.

Extraction replicas were prepared in the following route: samples were first prepared using standard metallographic techniques. After that, they were etched with the above-mentioned solution for $15 \mathrm{~s}$. A thin carbon film was sputtered onto the etched surface of the samples. The carbon film (replica) was subsequently electrolytically extracted, using $8 \%$ perchloric acid, at a bias of $10 \mathrm{~V}$.

\section{RESULTS}

Figure 2 shows the microstructure of material A after the special heat treatment. Light microscopy revealed a polyhedral grain, the presence of twins as well as the grain-size heterogeneity in material A. Two types of grain-boundary morphology were observed with light microscopy. Straight boundaries with a percentage share of approximately $38 \%$ of the total of 254 observed grain boundaries were located in the structure of material A. Serrated boundaries, as the second type, covered approximately $39 \%$ of the noticed boundaries. In some cases, the type of boundary could not be determined owing to the state of the boundary.

As a reference sample, material B (Figure 3) was processed with the conventional heat treatment. In material $\mathrm{B}$, we also observed the base microstructure 


\section{SLATKOVSKÝ et al.: INVESTIGATION OF GRAIN BOUNDARIES IN ALLOY 263 AFTER SPECIAL HEAT TREATMENT}

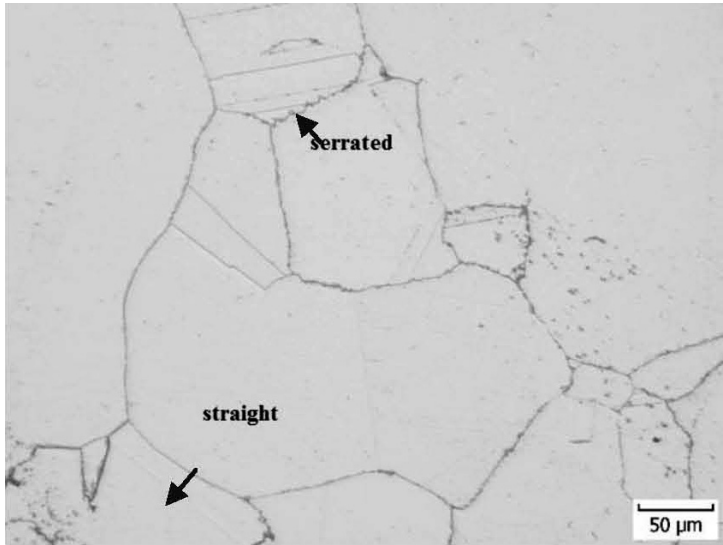

Figure 2: Material A

with polyhedral grains with the heterogeneity of the grain size and twins similar to those in material A. As expected, no serrated boundaries were observed in material B after the conventional heat treatment.

The grain-boundary details taken with SEM indicate the presence of precipitates on the serrated and straight grain boundaries in material $\mathrm{A}$ as well as in material $\mathrm{B}$ (Figures 4 and 5). Results of the EDX analysis taken from material A (Figure 6) reveal the eventual presence of carbon-rich secondary particles, which could possibly indicate the presence of carbides at the grain boundaries. The occurrence of the other elements at the grain boundaries was not significant. Comparable results were also noticed for material $\mathrm{B}$. To confirm the presence of the secondary particles formed at the boundaries and to identify the chemical nature of these particles, ED and EDX using the TEM were taken for materials A and B, and the results are shown below.

The authors of reference ${ }^{16}$ predicted and identified typical kinds of the secondary particles for this alloy, allowing us to expect mainly the presence of the MC, $\mathrm{M}_{6} \mathrm{C}$ and $\mathrm{M}_{23} \mathrm{C}_{6}$ carbides.

Figures 7 to 9 summarize the identified phases on the replicas for material A. Electron diffraction spectra as well as the EDX analysis of the extracted precipitates

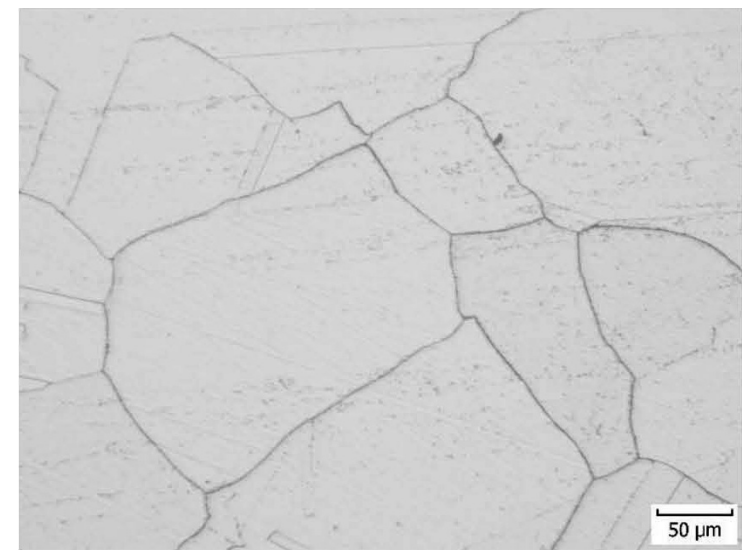

Figure 3: Material B

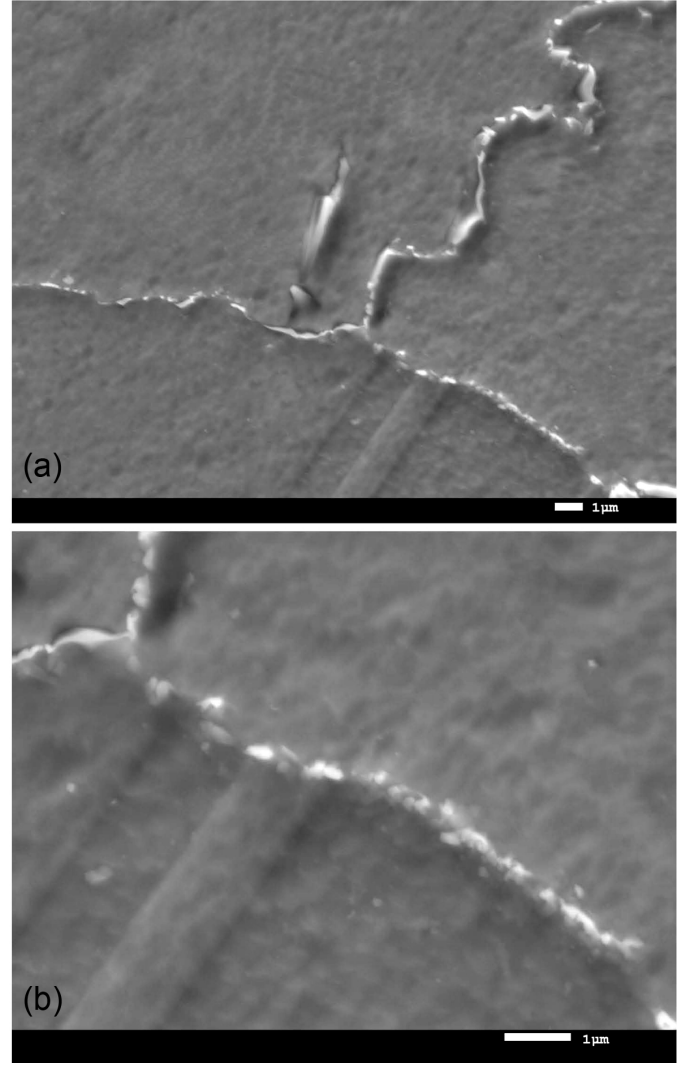

Figure 4: SEM, material A: a) serrated grain-boundary triple point and $b)$ detail of precipitates
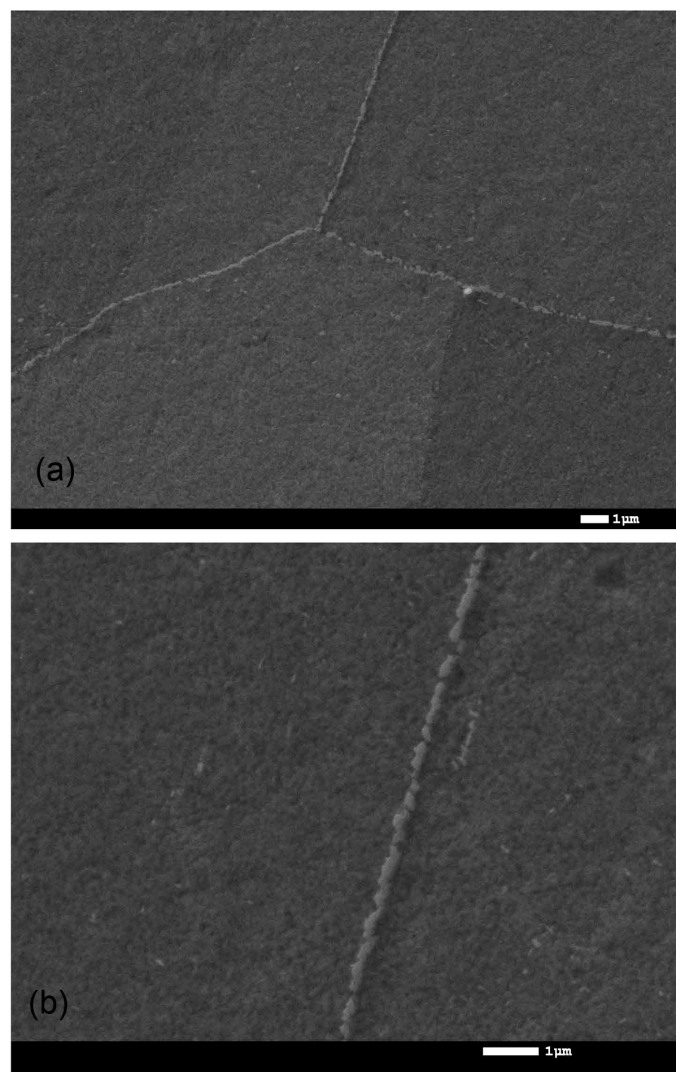

Figure 5: SEM, material B: a) straight grain-boundary triple point and b) detail of precipitates 

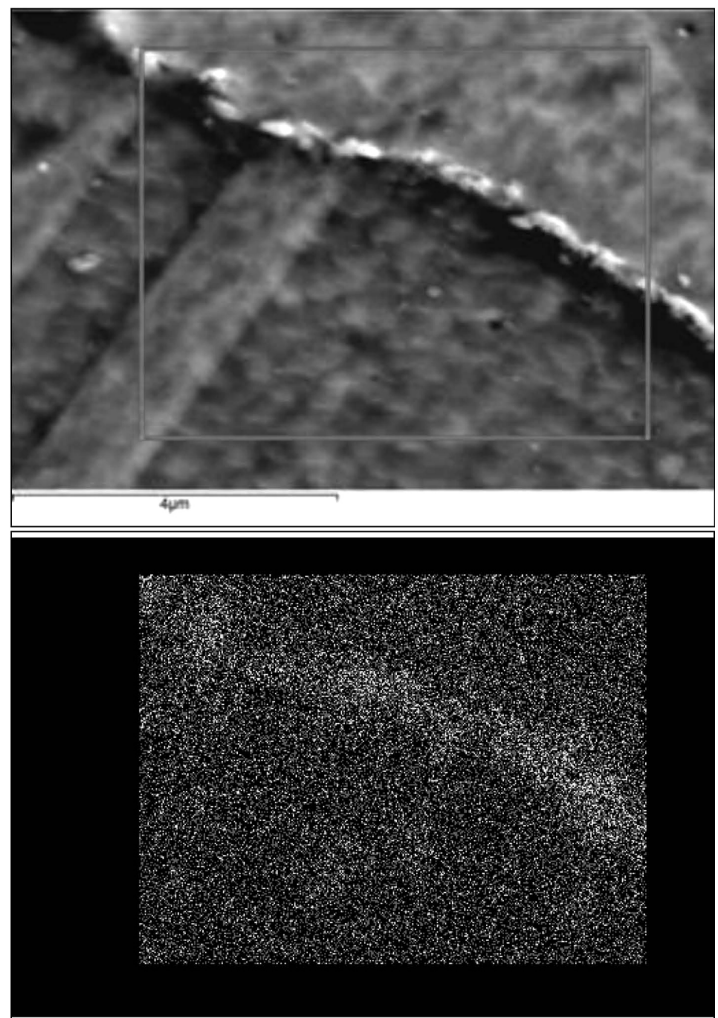

$\mathrm{C} \mathrm{K \alpha} \alpha_{1,2}$

Figure 6: EDX map, carbon-rich grain boundary, material A
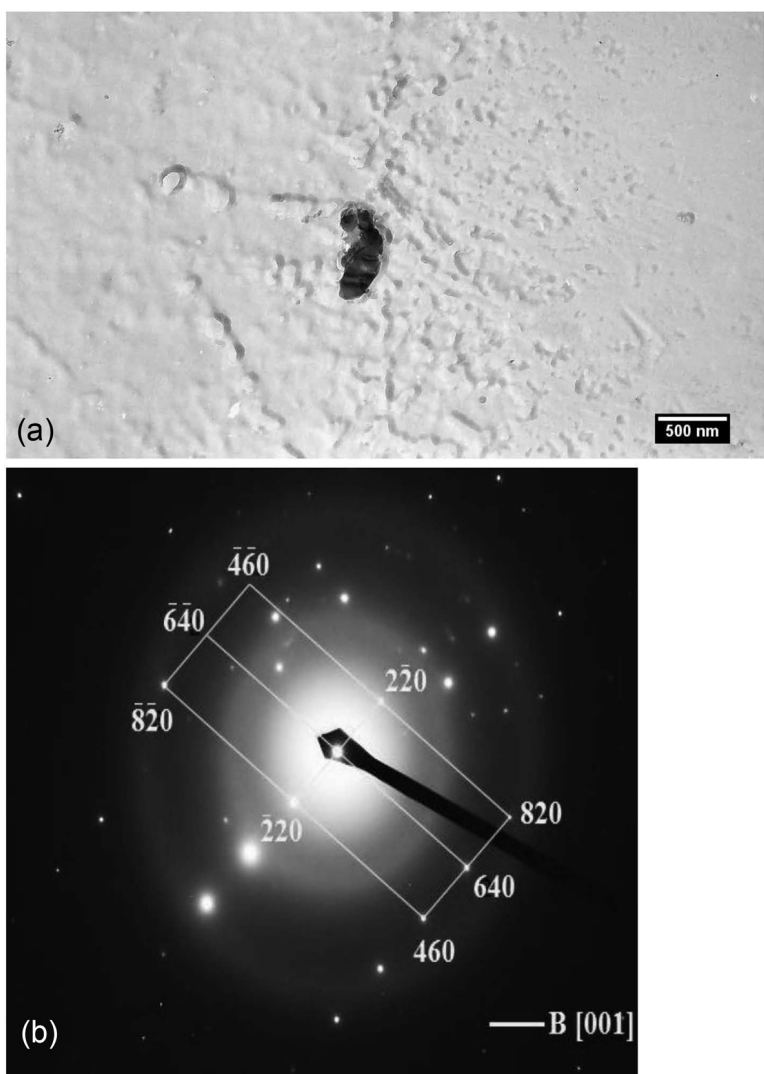

Figure 7: a) Detail of a precipitate at the grain boundary, material A and $b$ ) point-diffraction spectra of $\mathrm{M}_{23} \mathrm{C}_{6}$ carbide
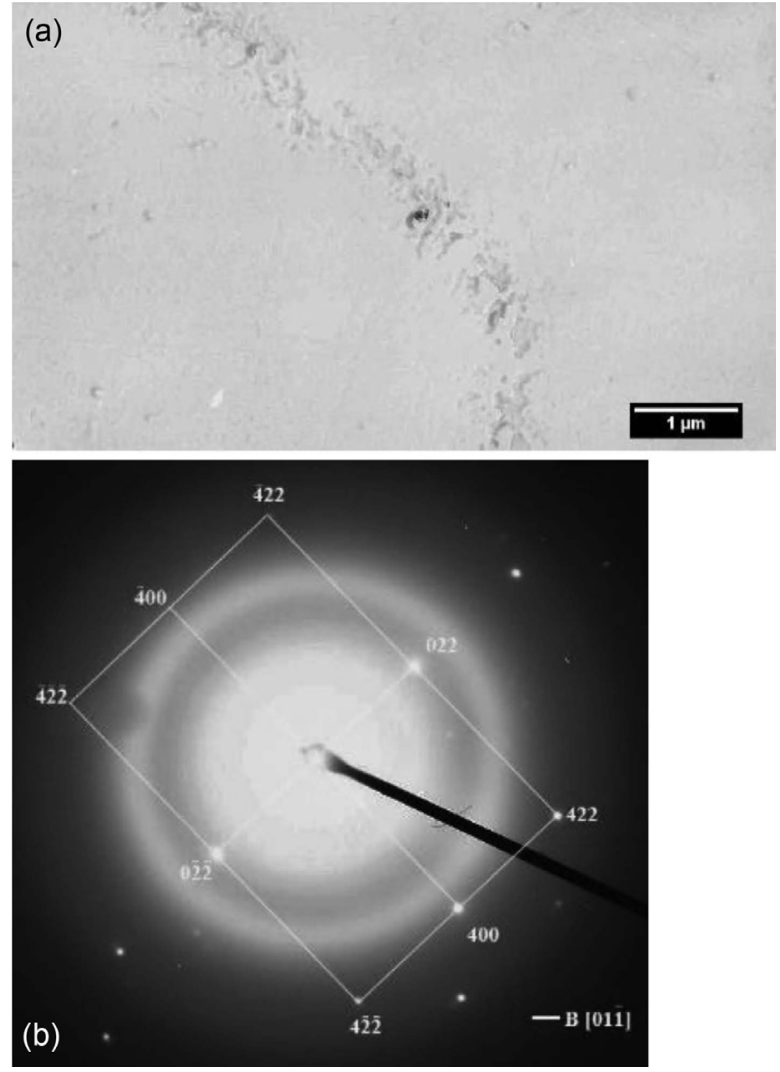

Figure 8: a) Extracted small particles of irregular shapes at the grain boundary, material $\mathrm{B}$ and $\mathrm{b}$ ) point-diffraction spectra of MC carbide

extracted at the grain boundaries confirmed the presence of carbides. The carbides contained minor elements such as $\mathrm{Mo}, \mathrm{Cr}$ and $\mathrm{Ni}$ (Table 2).

The $\mathrm{M}_{6} \mathrm{C}\left((\mathrm{Co}, \mathrm{Ni})_{3} \mathrm{Mo}_{3} \mathrm{C}\right)$ carbide was not confirmed by electron diffraction (confirmed only by the EDX anal-
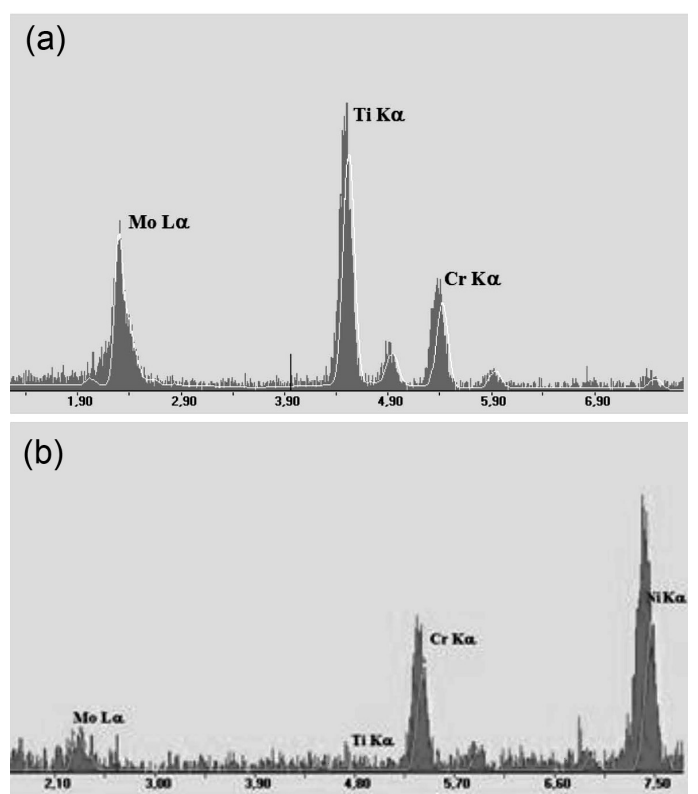

Figure 9: Typical EDX spectra of precipitates in material A: a) carbide $\mathrm{MC}$ and b) carbide $\mathrm{M}_{6} \mathrm{C}$ 
I. SLATKOVSKÝ et al.: INVESTIGATION OF GRAIN BOUNDARIES IN ALLOY 263 AFTER SPECIAL HEAT TREATMENT

ysis); a slight difference between the lattice parameters of the $\mathrm{M}_{23} \mathrm{C}_{6}$ and $\mathrm{M}_{6} \mathrm{C}\left(\mathrm{a}_{\mathrm{M} 23 \mathrm{C} 6}=0.1065 \mathrm{~nm} \mathrm{a}_{\mathrm{M} 6 \mathrm{C}}=0.1085\right.$ $\mathrm{nm})$ carbides makes the identification difficult.

Table 2: Approximate chemical composition of carbides in Material A

\begin{tabular}{|c|c|c|c|c|c|c|}
\hline \multirow{2}{*}{} & \multicolumn{2}{|c|}{$\mathrm{M}_{23} \mathrm{C}_{6}$} & \multicolumn{2}{c|}{ MC } & \multicolumn{2}{c|}{$\mathrm{M}_{6} \mathrm{C}$} \\
\cline { 2 - 7 } & Avr. $(w / \%)$ & $\sigma$ & Avr. $(w / \%)$ & $\sigma$ & Avr. $(w / \%)$ & $\sigma$ \\
\hline $\mathrm{Mo}$ & 28.6 & \pm 6.1 & 64.7 & \pm 6.3 & 22.9 & \pm 5.0 \\
\hline $\mathrm{Ti}$ & 4.6 & \pm 3.6 & 26.0 & \pm 5.0 & 3.3 & \pm 1.3 \\
\hline $\mathrm{Cr}$ & 66.8 & \pm 9.6 & 8.8 & \pm 4.3 & 27.5 & \pm 3.6 \\
\hline $\mathrm{Ni}$ & & & & & 46.3 & \pm 6.8 \\
\hline
\end{tabular}

Details of the serrated boundaries and precipitates in Material A, observed with TEM on the foils, can be seen in Figures 10a to 10b. As shown in the figures, the asymmetry of the serration was observed on some parts of the serrated boundaries when the irregularity of the serration exhibited a high difference in $\lambda$ at the observed parts of the boundary (on the edges, $\lambda=800-900 \mathrm{~nm}$; in the middle of the boundary, $\lambda=150-200 \mathrm{~nm}$ ).

On the serrated grain boundary documented in Figure 10b, secondary particles of different sizes were noticed. The shape of the particles copied the serration of the boundary. Using electron diffraction, the particles were identified as the $\mathrm{M}_{23} \mathrm{C}_{6}$ carbide and the matrix as the $\gamma$-phase (Figure 11). Electron diffraction also revealed the existence of the orientation relationship between the matrix and carbide: $\{200\}_{\gamma} \|\{200\}_{\text {M23C6 }}$.

Figure 12a documents a straight grain boundary with discrete secondary particles in material A. Along the full
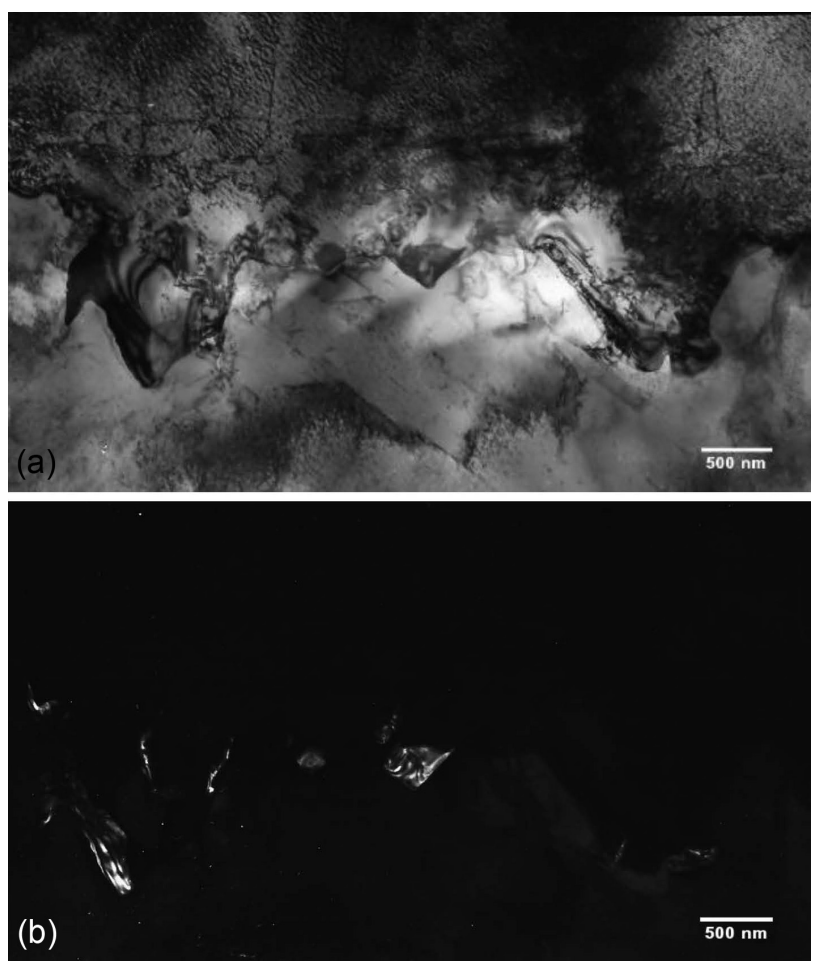

Figure 10: Detail of serrated grain boundary, material A, bright field; b) detail of precipitates at the grain boundary, material A, dark field; reflection $\left(\begin{array}{lll}2 & 0 & 0\end{array}\right) \mathrm{M}_{23} \mathrm{C}_{6}$ was used for the dark-field display

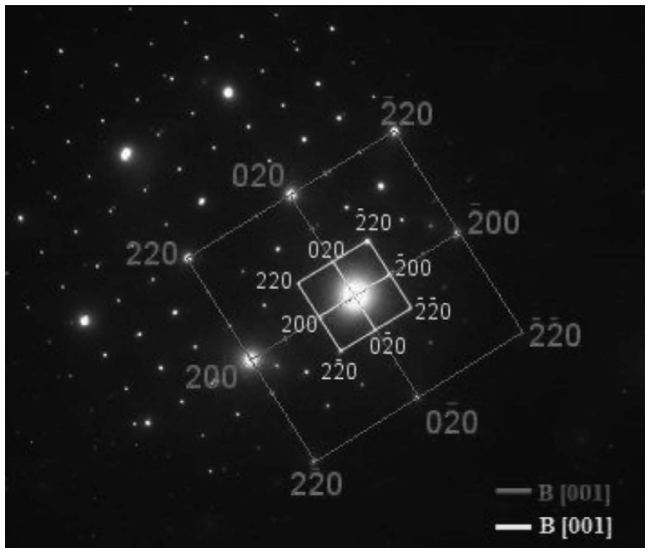

Figure 11: Point diffraction spectra - phase $\gamma$ and $\mathrm{M}_{23} \mathrm{C}_{6}$ carbide

length of the boundary, the particles of triangular or rectangular shapes were observed. As shown in Figure $\mathbf{1 2 b}$, this kind of particles does not copy the shape of the boundary as in the case of the precipitates at the serrated boundaries. The size of the precipitates was approximately $300 \mathrm{~nm}$. The particles were identified, with electron diffraction (Figure 13), as $\mathrm{M}_{23} \mathrm{C}_{6}$ carbide and the matrix as phase $\gamma$. However, in the case of the straight grain boundary, no orientation relationship between the matrix and the precipitate was spotted.

The precipitates extracted at the grain boundary in material $\mathrm{B}$ as $\mathrm{M}_{23} \mathrm{C}_{6}$ carbide were identified on the replicas using electron diffraction, as documented below

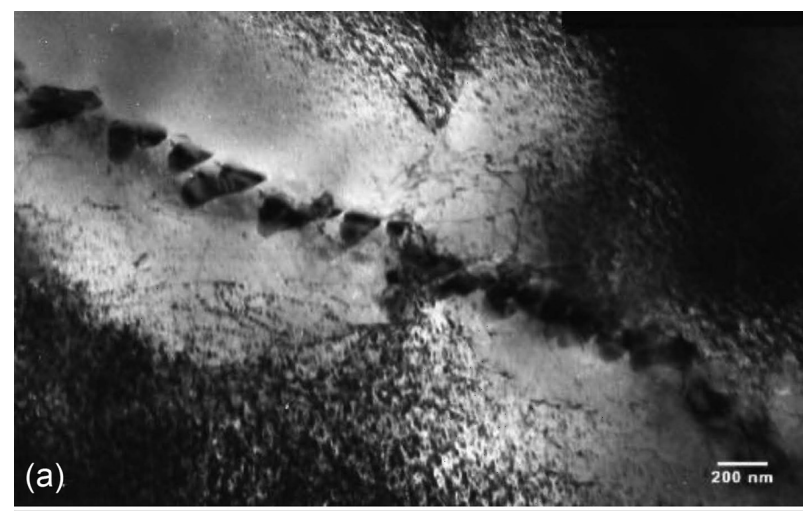

(b)

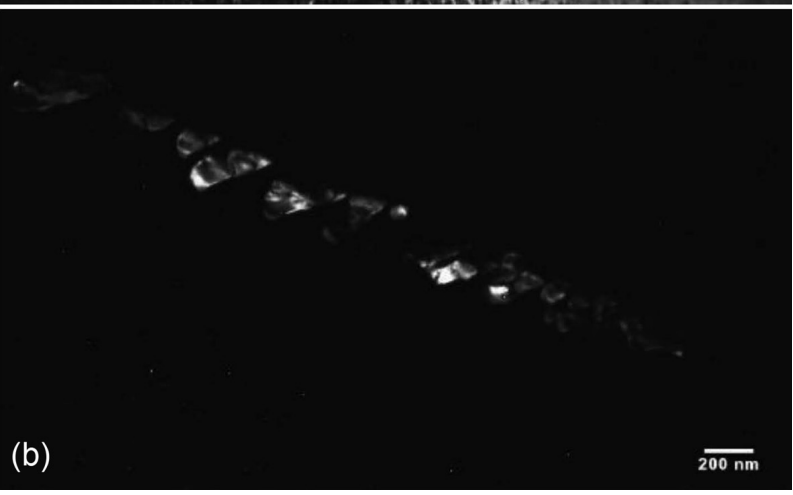

Figure 12: Detail of straight grain boundary, material A, bright field; b) detail of precipitates at the grain boundary, material A, dark field; reflection $(2-24)_{\mathrm{M} 23 \mathrm{C} 6}$ was used for the dark-field display 


\section{SLATKOVSKÝ et al.: INVESTIGATION OF GRAIN BOUNDARIES IN ALLOY 263 AFTER SPECIAL HEAT TREATMENT}

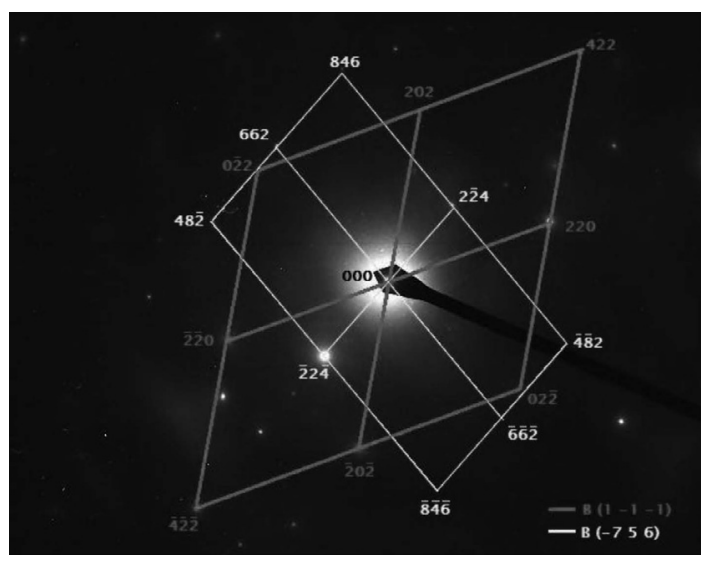

Figure 13: Point diffraction spectra - phase $\gamma$ and $\mathrm{M}_{23} \mathrm{C}_{6}$ carbide

in Figure 14. Other precipitates were not identified, which does not exclude their presence in Material B.

From the results of the EDX analysis (Figure 15, Table 3) of the observed precipitates in Material B, the presence of $\mathrm{MC}$ and $\mathrm{M}_{6} \mathrm{C}$ carbides is also possible.

Figures 16a to $\mathbf{1 6 b}$ document details of straight boundaries and precipitates at the grain boundary in material $\mathrm{B}$ on the foils. It can be noticed that the secondary particles extracted at the grain boundaries have a polyhedral or rectangular shape, and none of the observed particles copies the shape of the boundary. The size of these precipitates is in range of 100-200 $\mathrm{nm}$.

(a)

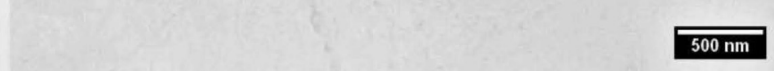

(b)

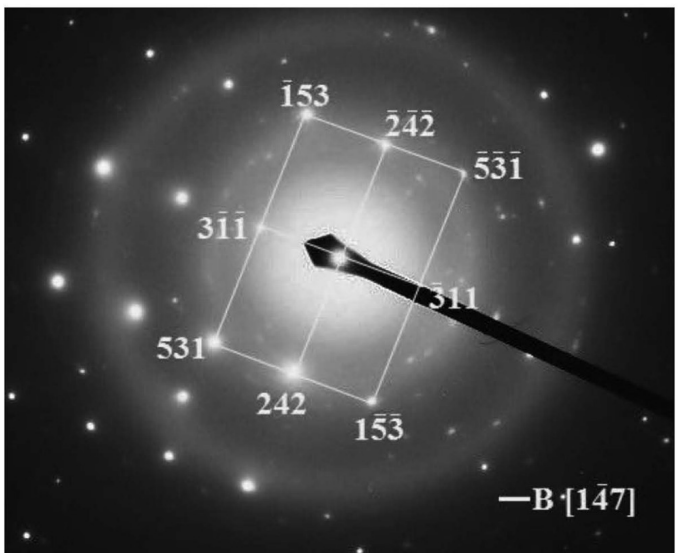

Figure 14: Extracted small particle of an irregular shape at the grain boundary, material $\mathrm{A}$; b) point diffraction spectra of $\mathrm{M}_{23} \mathrm{C}_{6}$ carbide
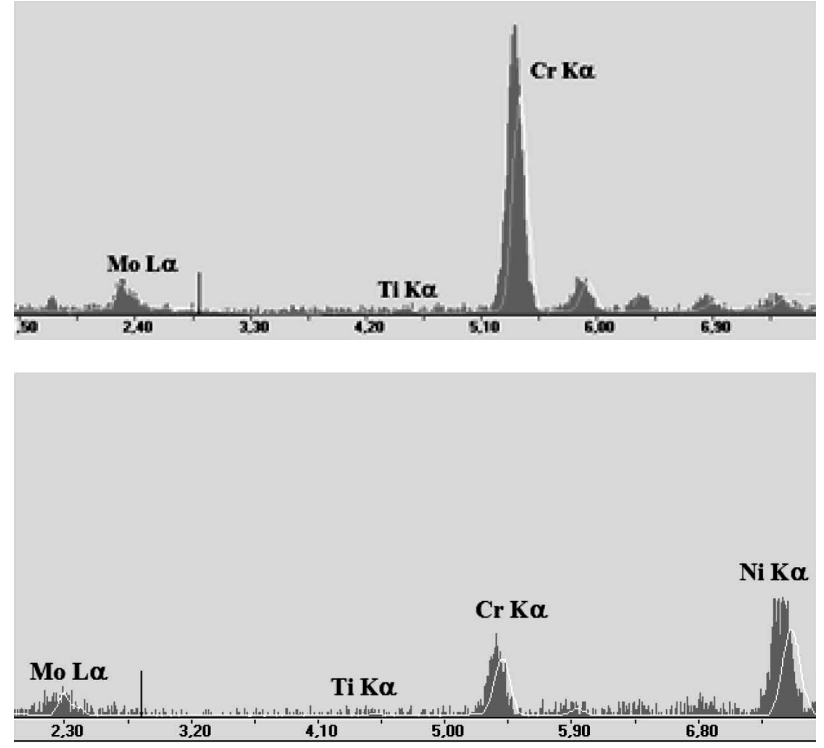

Figure 15: Typical EDX spectra of precipitates in material B: a) $\mathrm{M}_{23} \mathrm{C}_{6}$ carbide, b) $\mathrm{M}_{6} \mathrm{C}$ carbide

Table 3: Approximate chemical composition of carbides in material B

\begin{tabular}{|c|c|c|c|c|c|c|}
\hline & \multicolumn{2}{|c|}{$\mathrm{M}_{23} \mathrm{C}_{6}$} & \multicolumn{2}{c|}{$\mathrm{MC}$} & \multicolumn{2}{c|}{$\mathrm{M}_{6} \mathrm{C}$} \\
\hline & Avr. $(w / \%)$ & $\sigma$ & Avr. $(w / \%)$ & $\sigma$ & Avr. $(w / \%)$ & $\sigma$ \\
\hline $\mathrm{Mo}$ & 27.3 & \pm 6.4 & 62.9 & \pm 5.6 & 24.6 & \pm 3.2 \\
\hline $\mathrm{Ti}$ & 4.3 & \pm 4.9 & 25.0 & \pm 4.7 & 4.1 & \pm 1.8 \\
\hline $\mathrm{Cr}$ & 61.7 & \pm 9.4 & 10.5 & \pm 3.5 & 26.0 & \pm 3.1 \\
\hline $\mathrm{Ni}$ & & & & & 42.6 & \pm 5.1 \\
\hline
\end{tabular}
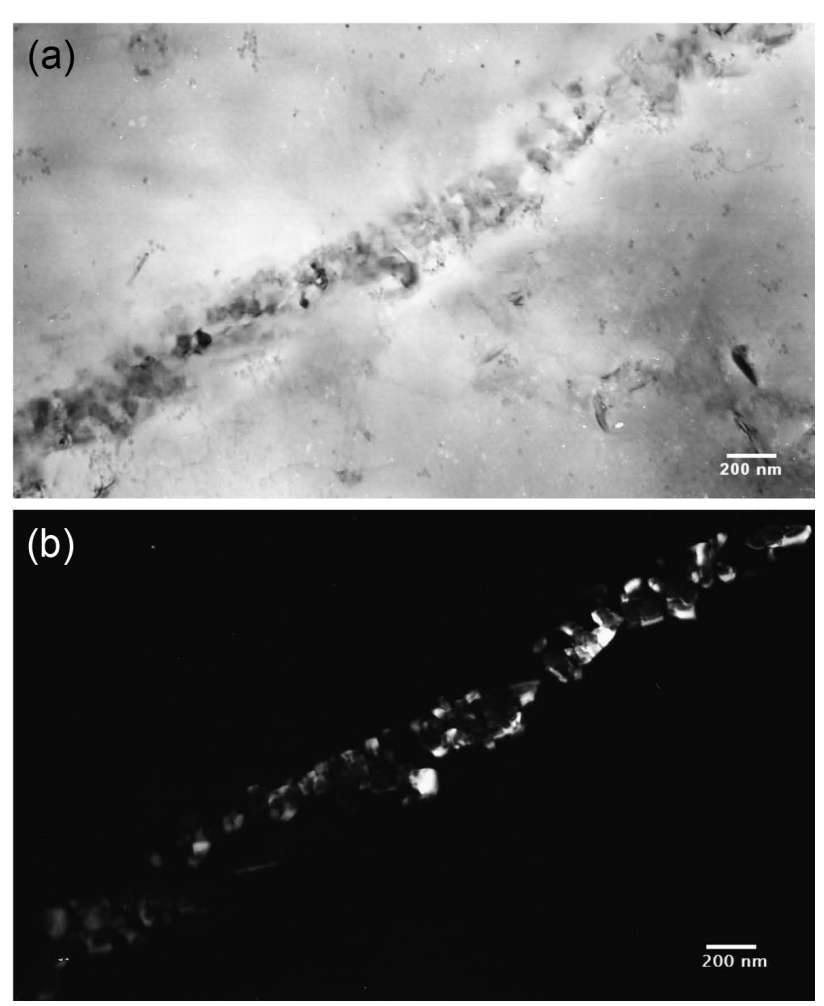

Figure 16: Detail of straight grain boundary, material B, bright field; b) detail of precipitates at the grain boundary, material B, dark field; reflection $(5-1-3)_{\mathrm{M} 23 \mathrm{C} 6}$ was used for the dark-field display 


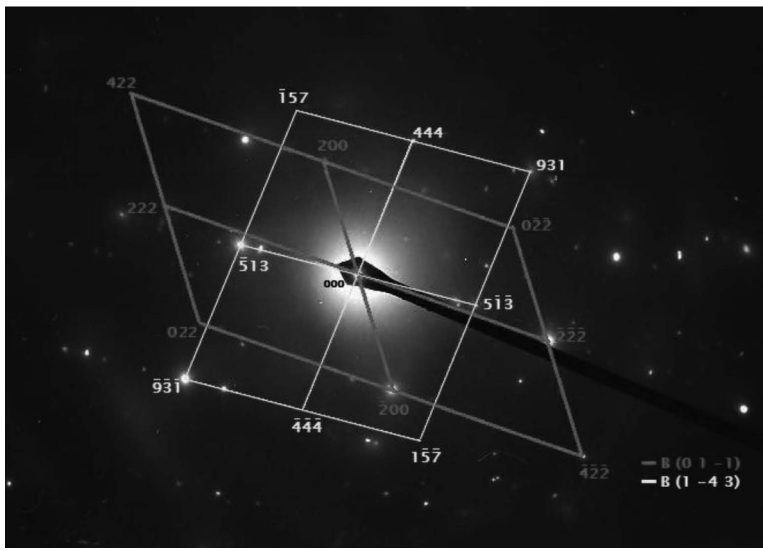

Figure 17: Point diffraction spectra - phase $\gamma$ and $\mathrm{M}_{23} \mathrm{C}_{6}$ carbide

From the diffraction spectra (Figure 17), secondary particles at the grain boundaries were identified as $\mathrm{M}_{23} \mathrm{C}_{6}$ carbide. No relationship between the matrix and precipitate was observed in all the diffraction spectra in material B.

\section{CONCLUSION}

To study the serration and precipitates at the grain boundaries and identify secondary particles in Alloy 263, both SEM and TEM were used in the research. To form serrated grain boundaries, material A was heat treated under special conditions, based on the studies from the literature. Material A was compared with material B, which underwent the conventional heat treatment based on the material list for Alloy 263. The experimental results can be summarized as follows:

- Serrated and straight grain boundaries were observed in material A. Approximately $39 \%$ of the observed boundaries were serrated. In material B, only straight grain boundaries were observed.

- In both cases, precipitates at the grain boundaries were identified as carbide $\mathrm{M}_{23} \mathrm{C}_{6}$ using electron diffraction. In material $\mathrm{A}$, carbide $\mathrm{MC}$ was also observed.

- The EDX analysis revealed three types of carbides, based on their chemical compositions, in both materials: $\mathrm{MC}, \mathrm{M}_{6} \mathrm{C}$ and $\mathrm{M}_{23} \mathrm{C}_{6}$.

- Electron diffraction also revealed the orientation relationship between the matrix and the precipitate at the serrated grain boundaries: $\{200\}_{\gamma}\{200\}_{\mathrm{M} 23 \mathrm{C} 6}$. No orientation relationship was observed at the straight grain boundaries.

\section{Acknowledgments}

The authors wish to thank the financial support of the Slovak Republic Scientific Grant Agency (VEGA) within Grant No. 1/0402/13.

\section{REFERENCES}

${ }^{1}$ P. J. Maziasz, I. G. Wright, J. P. Shingledecker, T. B. Gibbons, R. R. Romanosky, Defining the materials issues and research needs for ultra-supercritical steam turbines, Proc. $4^{\text {th }}$ Inter. Conf. Advances in Materials Technology for Fossil Power Plants, Hilton Head Island, USA, 2005, 602-622

${ }^{2}$ R. J. Campbell, Increasing the Efficiency of Existing Coal-Fired Power Plants, https://fas.org/sgp/crs/misc/R43343.pdf, 14.06.2017

${ }^{3}$ G. Stein-Brzozowska, D. M. Flórez, J. Maier, G. Scheffknecht, Nickel-base superalloys for ultra-supercritical coal-fired power plants: Fireside corrosion. Laboratory studies and power plant exposures, Fuel, 108, (2013), 521-533, doi:10.1016/j.fuel.2012.11.081

${ }^{4}$ A. K. Koul, G. H. Gessinger, On the mechanism of serrated grain boundary formation in Ni-based superalloys, Acta Metallurgica, 31, (1983) 7, 1061-1069, doi:10.1016/0001-6160(83)90202-X

${ }^{5}$ H. L. Danflou, M. Marty, A. Walder, Formation of serrated grain boundaries and their effect on the mechanical properties in a P/M nickel base superalloy, Proc. $7^{\text {th }}$ Inter. Symp. on Superalloys, Seven Springs Mountain, USA, 1992, 63-72, doi:10.7449/1992/ Superalloys_1992_63_72

${ }^{6}$ R. J. Mitchell, H. Y. Li, Z. W. Huang, On the formation of serrated grain boundaries and fan type structures in an advanced polycrystalline nickel-base superalloy, Journal of Materials Processing Technology, 209 (2009) 2, 1011-1017, doi:10.1016/j.jmatprotec.2008. 03.008

${ }^{7}$ C. L. Qiu, P. Andrews, On the formation of irregular-shaped gamma prime and serrated grain boundaries in a nickel-based superalloy during continuous cooling, Materials Characterization, 76 (2013), 28-34, doi:10.1016/j.matchar.2012.11.012

${ }^{8}$ A. C. Yeh, K. W. Lu, C. M. Kuo, H. Y. Bor, C. N. Wei, Effect of Serrated Grain Boundaries on the Creep Property of Inconel 718 Superalloy, Materials Science and Engineering A, 530 (2011), 525-529, doi:10.1016/j.msea.2011.10.014

${ }^{9}$ D. H. Ping, Y. F. Gu, C. Y. Cui, H. Harada, Grain boundary segregation in a Ni-Fe-based (Alloy 718) superalloy, Materials Science and Engineering A, 456 (2007) 1-2, 99-102, doi:10.1016/j.msea. 2007.01.090

${ }^{10}$ L. Jiang, R. Hu, H. Kou, J. Li, G. Bai, H. Fu, The effect of $\mathrm{M}_{23} \mathrm{C}_{6}$ carbides on the formation of grain boundary serrations in a wrought Ni-based superalloy, Materials Science and Engineering A, 536 (2012), 37-44, doi:10.1016/j.msea.2011.11.060

${ }^{11}$ Y. S. Lim, D. J. Kim, S. S. Hwang, H. P. Kim, S. W. Kim, $\mathrm{M}_{23} \mathrm{C}_{6}$ precipitation behavior and grain boundary serration in Ni-based Alloy 690, Materials Characterization, 96 (2014), 28-39, doi:10.1016/j.matchar.2014.07.008

${ }^{12}$ H. U. Hong, I. S. Kim, B. G. Choi, M. Y. Kim, C. Y. Jo, The effect of grain boundary serration on creep resistance in a wrought nickel-based superalloy, Materials Science and Engineering A, 517 (2009) 1-2, 125-131, doi:10.1016/j.msea.2009.03.071

${ }^{13}$ H. U. Hong, I. S. Kim, B. G. Choi, Y. S. Yoo, C. Y. Jo, On the role of grain boundary serration in simulated weld heat-affected zone liquation of a wrought nickel-based superalloy, Metallurgical and Materials Transactions A, 43 (2012) 1, 173-181, doi:10.1007/ s11661-011-0837-2

${ }^{14}$ H. U. Hong, I. S. Kim, B. G. Choi, Y. S. Yoo, C. Y. Jo, On the Mechanism of Serrated Grain Boundary Formation in Ni-Based Superalloys with Low $\gamma^{\prime}$ ? Volume Fraction, Proc. 12th Inter. Symp. on Superalloys, Seven Springs Mountain, USA, 2012, 53-61, doi:10.1002/9781118516430.ch6

${ }^{15}$ H. U. Hong, F. H. Latief, T. Blanc, I. S. Kim, B. G. Choi, C. Y. Jo, J. $\mathrm{H}$. Lee, Influence of chromium content on microstructure and grain boundary serration formation in a ternary $\mathrm{Ni}-\mathrm{xCr}-0.1 \mathrm{C}$ model alloy, Materials Chemistry and Physics, 148 (2014) 3, 1194-1201, doi:10.1016/j.matchemphys.2014.09.047

${ }^{16}$ J. C. Zhao, V. Ravikumar, A. M. Beltran, Phase Precipitation and Phase Stability in Nimonic 263, Metallurgical and Materials Transactions A, 32 (2001) 6, 1271-1282, doi:10.1007/s11661001-0217-4 